Bangl. J. Vet. Med. (2011). 9(1): 67 - 71

\title{
CHARACTERIZATION OF BACTERIA ASSOCIATED WITH PNEUMONIA IN BLACK BENGAL GOATS
}

\author{
M. A. Momin, M. A. Islam*, M. M. Khatun, M. M. Rahman and M. A. Islam \\ Department of Microbiology and Hygiene, Faculty of Veterinary Science, \\ Bangladesh Agricultural University, Mymensingh-2202, Bangladesh
}

\begin{abstract}
The present research work was undertaken for the characterization of the bacterial pathogens responsible for pneumonia in black Bengal goats. Nasal swab samples $(\mathrm{n}=50)$ were collected from the pneumonic black Bengal goats in Mymensingh and Sirajgonj districts. Samples were inoculated onto nutrient agar, eosin methylene blue (EMB) agar, MacConkey agar, and blood agar media for isolation of bacteria. Identification of bacteria was performed by the Gram's staining method, cultural properties and biochemical tests. Antibiotic sensitivity of bacterial isolates was performed against 11 antimicrobial agents. Pasteurella spp were isolated from 25 cases, and Staphylococcus spp from 13 cases. Mixed infection caused by the Pasteurella spp and Staphylococcus spp. were recorded in 12 cases. Pasteurella spp produced whitish, opaque circular and translucent colonies on nutrient agar, smooth, convex, glistening colonies on EMB agar and no hemolysis on blood agar. Staphylococcus spp have shown gray white or golden yellowish colonies on nutrient agar. Golden yellow colonies without hemolysis or whitish colonies with hemolysis were also produced by Staphylococcus spp. on the blood agar media. Pasteurella spp were indole positive, MR-VP negative and ferment dextrose, sucrose and mannitol with the production of acid. The Staphylococcus spp were positive to MR-VP, coagulase and catalase reactions, negative to indole test and fermented five basic sugars with acid production. Results of cultural and biochemical tests supported that these two isolates belonged to $P$. multocida and $S$. aureus. P. multocida were highly sensitive to ciprofloxacin and resistant to penicillin. S. aureus found to be highly sensitive to erythromycin, tetracycline, enrofloxacin, and norfloxacin and less sensitive to amoxicillin.
\end{abstract}

Key words: Goats, pneumonia, bacteria, antimicrobial agents

\section{INTRODUCTION}

Goat is the second important livestock in Bangladesh. It plays an important role in the rural economy and earns substantial amount of foreign currency through exporting skin and other by products (Alam, 1993). The estimated goat population in Bangladesh in 2002 was 36.9 million and in 2001 was 34.4 million (FAO, 2003), most of which belong to black Bengal breed (Rahman et al., 1976). It is mainly reared for meat, milk and leather production (Faruk et al., 2006). Rearing of goat is easy, less expensive, less laborious and highly profitable. In Bangladesh goat farming is substantially hampered due to outbreaks of diseases.

Pneumonia in goat is an infection of the lungs characterized by fever $\left(40-41^{\circ} \mathrm{C}\right)$, anorexia, painful coughing, dyspnea, mucopurulent nasal discharge and depression. It is one of the most common respiratory illnesses in goats throughout the world (Ackermann and Brogden, 2000). Although pneumonia is more frequently occur in kids but it also infects adult goats. Both infectious and non infectious agents are responsible for lung affection. Among the infectious agents Pasteurella maltocida and Pasteurella haemolytica are more frequently associated with the outbreak of acute pneumonia and death of goats in all age (Falade, 2002). These bacteria are commonly found in the upper respiratory tract of healthy goats. Poor managemental condition, transportation stress, overcrowding pens, sudden environmental changes, poor housing conditions, viral infection (e.g. parainfluenza-3 virus), lung parasites and other stressful conditions increase goats' susceptibility to pneumonias. Pneumonia caused by $P$. multocida and $P$. haemolytica can lead to wide spread financial losses because of death, reduced live weight, delayed marketing, treatment cost and unthriftiness among survivors (Davies et al., 1997; Daniel et al., 2006).

*Corresponding e-mail address:

Copyright $\odot 2011$ Bangladesh Society for Veterinary Medicine

All right reserved 1729-7893/0224/2011 


\section{M.A. Momin and others}

Pneumonias were reported in the black Bengal goats in Bangladesh (Islam et al. 2006). To the best of our knowledge there is no report concerning the characterization of bacterial pathogens causing pneumonia in the black Bengal goats in Bangladesh. Identification of bacteria is essential for undertaking effective prevention and control measures against pneumonia in black Bengal goats. This study was therefore designed to characterize the bacterial pathogens associated with pneumonia and selection of appropriate antibiotic for treatment of this disease in goats.

\section{MATERIALS AND METHODS}

\section{Collection of specimens}

Nasal swab samples $(n=50)$ were aseptically collected from the pneumonic Black Bengal goats from Ullaparasadar upazilla, Sirajgang; Bangladesh Agricultural University (BAU) goat farm and BAU veterinary clinic. Goats were manifested the clinical signs of fever $\left(40-41{ }^{\circ} \mathrm{C}\right)$, anorexia, mucopurulent nasal discharge, coughing, anorexia and depression.

\section{Isolation of bacteria}

Nasal swab samples were inoculated separately onto the nutrient agar and blood agar, eosin methylene blue (EMB) agar and MacConkey agar media and incubated at $37^{\circ} \mathrm{C}$ for 24 hours. The colonies on primary cultures were repeatedly sub-cultured by steak plate method until the pure cultures with homogenous colonies were obtained (Cheesbrough, 1985).

\section{Characterization of bacteria}

In order to identify and differentiate bacterial pathogens isolated from pneumonic goats different characteristics of bacteria such as: cultural characteristics, cellular characteristics and biochemical characteristics were studied.

Cultural characteristics or colonial morphology (e.g. size, margin, elevation and colour) of bacteria grown on the nutrient and blood agar media were recorded. Gram's staining method was performed to study the cellular morphology and staining characteristics of bacteria according to the technique described by Merchant and Packer (1967). Biochemical tests such as: sugar fermentation, coagulase, catalase, M-R, V-P and indole tests were performed according to the standard methods (Cheesbrough, 1985).

\section{Antibiotic sensitivity assay}

Disc diffusion assay was used to determined antimicrobial susceptibility of isolates against 11 different antimicrobial agents such as: amoxicillin, ampicillin, penicillin, tetracycline, erythromycin, azithromycin, enrofloxacin, norfloxacin, furazolidone, gentamicin and ciprofloxacin following the standard methods (NCCLS, 2003).

\section{RESULTS AND DISCUSSION}

\section{Isolation of bacteria}

Fifty nasal swabs were collected from 50 goats. Pasteurella spp were recovered from 25 cases and Staphylococcus spp were isolated from 13 cases. Mixed infection caused by Pasteurella spp and Staphylococcus spp were recorded in 12 cases. The distribution of bacteria in the nasal swab samples of pneumonic black Bengal goats is shown in Table1.

Table 1. Distribution of the bacteria in the nasal swabs samples of pneumonic black Bengal goats

\begin{tabular}{|ccc|}
\hline $\begin{array}{c}\text { No. of goats } \\
\text { examined }\end{array}$ & Name of bacteria & No. of culture positive samples (\%) \\
\hline \multirow{2}{*}{50} & Pasteurella $\mathrm{spp}$ & $25(50)$ \\
& Staphylococcus $\mathrm{spp}$ & $13(26)$ \\
& Pasteurella spp + Staphylococcus spp & $12(24)$ \\
\hline
\end{tabular}


Berge et al., (2006) isolated P. multocida and P. hemolytica from the respiratory tract of sheep and goats. Yimer and Asseged (2007) also reported Staphylococcus spp, E. coli, Corynebacter spp, Klebsiella spp and Bacillus spp in the respiratory tract of sheep. Data of bacterial isolation in our study are in agreement with the findings of Oros et al., (1997), Ozbey and Muz (2004) and Shafarin et al., (2007).

\section{Cultural, morphological and staining characteristics}

Staphylococcus spp and Pasteurella spp were grown in the nutrient agar and blood agar media. No growths of Staphylococcus spp were noticed on the EMB and MacConkey agar media. Both hemolytic and non-hemolytic Staphylococcus spp were recovered from the nasal swab samples. Pasteurella spp did not produce hemolysis on blood agar. Pasteurella spp were grown on EMB agar but did not grow on MacConkey agar. Staphylococcus spp were round shaped arranged in clustered and showed Gram positive reaction. Pasteurella spp were Gram negative, coccobacillary shaped arranged in single or pair form. These results are in agreement with Heddleston and Wessman (1975) and Mork et al., (2010). The summary of cultural, morphological and staining characteristics of bacteria recovered from nasal swabs is given in Table 2.

Table 2. Summary of cultural and staining characteristics of bacteria isolated from nasal swabs of pneumonic black Bengal goats

\begin{tabular}{|c|c|c|c|c|c|c|}
\hline \multicolumn{3}{|c|}{ Cultural characteristics } & \multicolumn{3}{|c|}{ Staining characteristics } & \multirow{2}{*}{$\begin{array}{l}\text { Identified } \\
\text { organisms }\end{array}$} \\
\hline Nutrient agar & Blood agar & $\begin{array}{l}\text { Eosine- } \\
\text { Methylene } \\
\text { Blue agar }\end{array}$ & Shape & Arrangement & $\begin{array}{l}\text { Gram's } \\
\text { staining } \\
\text { reaction }\end{array}$ & \\
\hline $\begin{array}{l}\text { Gray white or } \\
\text { golden } \\
\text { yellowish } \\
\text { colony }\end{array}$ & $\begin{array}{l}\text { Golden yellow } \\
\text { colony without } \\
\text { hemolysis or } \\
\text { whitish colony } \\
\text { with hemolysis }\end{array}$ & No growth & Cocci & Cluster & $\begin{array}{l}\text { Gram } \\
\text { positive }\end{array}$ & $\begin{array}{l}\text { Staphyloco } \\
\text { ccus spp }\end{array}$ \\
\hline $\begin{array}{l}\text { Whitish, } \\
\text { opaque circular } \\
\text { and translucent } \\
\text { colony }\end{array}$ & $\begin{array}{l}\text { Whitish, opaque } \\
\text { circular colony } \\
\text { with no } \\
\text { hemolysis }\end{array}$ & $\begin{array}{l}\text { Smooth, } \\
\text { convex, } \\
\text { glistening } \\
\text { colony }\end{array}$ & $\begin{array}{l}\text { Cocco- } \\
\text { bacillary }\end{array}$ & $\begin{array}{l}\text { Single or pair } \\
\text { form }\end{array}$ & $\begin{array}{l}\text { Gram } \\
\text { negative }\end{array}$ & $\begin{array}{l}\text { Pasteurella } \\
\text { spp }\end{array}$ \\
\hline
\end{tabular}

\section{Biochemical Characteristics}

Staphylococcus spp fermented five basic sugars such as: dextrose, maltose, lactose, sucrose and mannitol. Pasteurella spp fermented only three basic sugars: dextrose, sucrose and mannitol. Only acid production was noticed following sugar fermentation reaction by these bacteria. Staphylococcus spp were positive to catalase, coagulase, MR and VP tests. Indole test was negative for Staphylococcus spp. Pasteurella spp were catalase, coagulase, MR and VP negative and indole positive. These results are in accordance with Tefera and Smola (2002) and OIE manual (2004). The summary of biochemical characteristics is shown in Table 3.

Table 3. Summary of biochemical characteristics of bacteria isolated from nasal swabs of pneumonic black Bengal goats

\begin{tabular}{|c|c|c|c|c|c|c|c|c|c|c|}
\hline \multicolumn{5}{|c|}{$\begin{array}{l}\text { Fermentation reactions with } \\
\text { carbohydrates }\end{array}$} & \multirow[t]{2}{*}{$\begin{array}{c}\text { Catalase } \\
\text { test }\end{array}$} & \multirow[t]{2}{*}{$\begin{array}{c}\text { Coagulase } \\
\text { test }\end{array}$} & \multirow[t]{2}{*}{$\begin{array}{l}\text { MR } \\
\text { test }\end{array}$} & \multirow[t]{2}{*}{$\begin{array}{l}\mathrm{VP} \\
\text { test }\end{array}$} & \multirow[t]{2}{*}{$\begin{array}{c}\text { Indole } \\
\text { test }\end{array}$} & \multirow[t]{2}{*}{ Identified organisms } \\
\hline $\mathrm{D}$ & ML & $\mathrm{L}$ & $\mathrm{S}$ & $\mathrm{MN}$ & & & & & & \\
\hline+ & + & + & + & + & + & + & + & + & - & Staphylococcus aureus \\
\hline+ & - & - & + & + & + & - & - & - & + & Pasteurella multocida \\
\hline
\end{tabular}

$\mathrm{D}=$ Dextrose $; \mathrm{ML}=$ Maltose $\mathrm{L}=$ Lactose $\mathrm{S}=$ Sucrose $; \mathrm{MN}=$ Mannitol $;+=$ Positive reaction $;-=$ Negative reaction 


\section{M.A. Momin and others}

Data of the biochemical and cultural characteristics indicated that isolated bacteria were Staphylocococcus aureus and Pasteurella multocida. These results are in agreement with Hawari et al., (2008) and Yimer and Asseged (2007). Similar results were also reported by Amaechi and Ugbogu (2006) and Tefera and Smola (2002).

\section{Antibiotic sensitivity assay}

Staphylococcus aureus were highly sensitive to tetracycline, erythromycin, enrofloxacin and noflaxacin, moderately sensitive to furazolidone and gentamycin, less sensitive to amoxicillin and penicillin. On the other hand Pasteurella multocida were highly sensitive to ciprofloxacin, moderately sensitive to tetracycline, erythromycin, azithromycin and gentamycin, less sensitive to ampicillin, amoxicillin and resistant to penicillin. Summary of antibiotic sensitivity pattern of bacteria isolated from nasal swabs of pneumonic black Bengal goats is furnished in Table 4.

Table. 4. Summary of antibiotic sensitivity pattern of bacteria isolated from nasal swabs of pneumonic black Bengal goats

\begin{tabular}{|c|c|c|c|c|c|c|c|c|c|c|c|}
\hline \multirow[t]{2}{*}{ Bacterial isolates } & \multicolumn{11}{|c|}{ Antibiotic sensitivity profiles } \\
\hline & A & AP & $P$ & $\mathrm{TE}$ & $\mathrm{E}$ & AZM & ENR & NOR & FR & GM & CIP \\
\hline $\begin{array}{l}\text { Staphylococcus } \\
\text { aureus }\end{array}$ & + & ND & ND & +++ & +++ & ND & +++ & +++ & ++ & ++ & ND \\
\hline $\begin{array}{l}\text { Pasteurella } \\
\text { multocida }\end{array}$ & + & + & - & ++ & ++ & ++ & ND & ND & ND & ++ & +++ \\
\hline
\end{tabular}

$\mathrm{E}=$ Erythromycin $; \mathrm{GM}=$ Gentamicin $; \mathrm{TE}=$ Tetracycline $; \mathrm{A}=$ Amoxycillin $; \mathrm{ENR}=$ Enrofloxacin; NOR = Norfloxacin; FR = Furazolidone; $\mathrm{AP}=$ Ampicillin, $\mathrm{CIP}=$ Ciprofloxacin; $\mathrm{AZM}=$ Azithromicin; $\mathrm{P}=\mathrm{Penicillin}$; $+++=$ Highly sensitive $;++=$ Moderately sensitive $;+=$ Less sensitive and $-=$ Resistant, ND = Not done

In clinical aspects antibiotic sensitive assay serves as a guide to choose the correct antibiotic to be used in the field (Coates and Hoops, 1980). The findings recorded in this study are in agreement with the result of Catry et al. (2002), Amaechi et al. (2006) and Berge et al. (2006). The results of antibiotic sensitivity assay recorded in this study are also in accordance with Kawamoto et al. (1990).

Data of this study indicated that the bacterial infections caused by $S$. aureus and $P$. multocida were responsible for pneumonia in black Bengal goat. Further study is required for molecular characterization of $S$. aureus and $P$. multocida isolated from pneumonic goats.

\section{ACKNOWLEDGEMENT}

This research work was funded by the Bangladesh Agricultural University Research System (BAURES) grants.

\section{REFERENCES}

1. Ackermann MR and Brogden KA (2000). Response of the ruminant respiratory tract to Mannheimia (Pasteurella) haemolytica. Microbes and Infection 2: 1079-1088.

2. Alam J (1993). Livestock: The sector for more investment in Bangladesh. Asian Livestock 7: 77-78.

3. Amaechi N and Ugbogu GA (2006). Antimicrobial susceptibility profile of Staphylococcus aureus isolates from ear and nostrils of farm animals at Michael Okpara University of Agriculture, Umudike Abia-State. Journal of Animal and Veterinary Advances 5: 882-885.

4. Berge AC, Sischo WM and Craigmill AL (2006). Antimicrobial susceptibility patterns of respiratory tract pathogens from sheep and goats. Journal of the American Veterinary Medical Association 229: 1279-1281.

5. Catry B, Govaere J , Devriese L, Laevens H, Haesebrouck F and Kruif A de (2002). Bovine enzootic bronchopneumonia: prevalence of pathogens and its antimicrobial susceptibility. Vlaams Diergeneeskundig Tijdschrift 71: 348-354. 
6. Cheesbrough M (1985). Medical laboratory manual for tropical countries. Vol. II. Microbiology. $1^{\text {st }}$ edn., pp. 400-480.

7. Coates SR and Hooper (1980). Sensitivities of E. coli isolated from bovine and procrine enteric infection to antimicrobial antibiotics. American Journal of Veterinary Research 41: 1882-1883.

8. Daniel JA, Held JE, Brake DG, Wulf DM and Epperson WB (2006). Evaluation of the prevalence and onset of lung lesions and their impact on growth of lambs. American Journal of Veterinary Research 67: 890-894.

9. Davies RL, Arkinsaw S, Selander RK (1997). Evolutionary genetics of Pasteurella hemolytica isolates recovered from cattle and sheep. Infection and Immunity 65: 3585-3593.

10. Falade S (2002). Further Pasteurella isolates from the republic of Zambia. Tropical Veterinarian 20: 130131.

11. FAO (2003). FAO Statistics on Livestock Population of Countries in Asia Pacific Region. FAO Quarterly Bulletin of Statistics, Rome, Italy.

12. Faruk MO, Bari FY, Shamsuddin MM, Alam GS and Islam MF (2006). Responses of the black Bengal goat (capra hircus) to PMSG and surgical embryo recovery within MOET technique. Bangladesh Journal of Veterinary Medicine 4: 107-115.

13. Hawari AD, Hassawi DS and Sweiss M (2008). Isolation and identification of Mannheimia haemolytica and Pasteurella multocida in sheep and goats using biochemical tests and random amplified polymorphic DNA (RAPD) analysis. Journal of Biological Science 8: 1251-1254.

14. Heddleston KL and Wessman G (1975) Characteristics of Pasteurella multocida of human origin. Journal of Clinical Microbiology 1: 377-383.

15. Islam S, Ahad A, Chowdhury S and Barua SR (2006). Study on pneumonia in black Bengal goat in selected areas of Bangladesh. Bangladesh Journal of Veterinary Medicine 4: 137-140.

16. Kawamoto E, Sawada T, Suzuki K and Maruyama T (1990). Serotypes of Pasteurella multocida isolates from rabbits and their environment in Japan. Nippon Juigaku Zasshi 52: 1277-1279.

17. Merchant I A and Packer RA (1967). Veterinary Bacteriology and Virology. $7^{\text {th }}$ edn., the Iowa University Press, Ames, Iowa, USA, pp. 64-65.

18. Mork T, Kvitle B, Mathisen T, Jorgensen HJ (2010) Bacteriological and molecular investigations of Staphylococcus aureus in dairy goats. Veterinary Microbiology 141: 134-141.

19. NCCLS (2003). Performance standards for antimicrobial disk susceptibility tests. Approved standard, $8^{\text {th }}$ edn., NCCLS document M2-A8. NCCLS, Wayne, Pa, USA.

20. OIE (2004). Manuals of standards for diagnostic test and vaccine. $4^{\text {th }}$ edn., France, pp $446-456$.

21. Oros J, Fernandez A, Rodriguez JL and Poveda JB (1997). Bacteria associated with enzootic pneumonia in goats. Journal of Veterinary Medicine series B 44: 99-104.

22. Ozbey G and Muz A (2004). Isolation of aerobic bacterial agents from the lungs of sheep and goats with pneumonia and detection of Pasteurella multocida and Mannheimia haemolytica by polymerase chain reaction. Turkish Journal of Veterinary and Animal Sciences 28: 209-216.

23. Rahman A, Ahmed MU and Mia AS (1976) Studies on the diseases of goats in Bangladesh: Mortality of goats under farm and rural conditions. Tropical Animal Health and Production 8: 90-91.

24. Shafarin MS, Zamri SM, Jamil SM, Khairani BS and Saharee AA (2007). Experimental transmission of Pasteurella multocida 6:B in goats. Journal of Veterinary Medicine series B 54: 136-139.

25. Tefera G and Smola J (2002). The utility of the ENTERO Rapid 24 kit for the identification of $P$. multocida and M. haemolytica. Veterinary Medicine-Czech 47: 99-103.

26. Yimer N and Asseged B (2007). Aerobic bacterial flora of the respiratory tract of healthy sheep slaughtered in Dessie municipal abattoir, northeastern Ethiopia. Revue de Medecine Veterinaire 158: 473-478. 